\title{
Economic evaluation of recreational use of forests roads on the example of Pisek City Forests Ltd.
}

\author{
David Březina, Petra Hlaváčková, Jitka Fialová $\bowtie$ \\ Mendel University in Brno, Faculty of Forestry and Wood Technology, Zemědělská 3, 61300 Brno, Czech Republic, \\ phone: +420 545134 096, e-mail: jitka.fialova@mendelu.cz
}

\begin{abstract}
An additional objective of the research, which was a part of the project "Quantification of the Effect of the Selected Forest Enterprise on the Local Economy of the Region" of the Internal Grant Agency (IGA) of Mendel University in Brno conducted in 2016 was a large case study of the property of Pisek City Forests Ltd. This article is focused on surveying the willingness of area visitors to pay for usage of the recreational function of forests and evaluation of the used method. The evaluated part of the questionnaire survey was based on the method of contingent valuation founded on the willingness of respondents to pay for recreational function. It was found in the results of the questionnaire survey that visitors are not very willing to pay for recreational function, and it is especially because forests in the area of Pisek City Forests Ltd. are perceived as public assets and thus access to them should be without fee. Furthermore, there were problems found with the method. Thus it is necessary to find a new way of evaluation of the recreational potential of the area.
\end{abstract}

\section{KeY WORDS}

case study, forestry, methods of valuation, questionnaire survey, recreation function, TCM, CVM

\section{INTRODUCTION}

The aim of this contribution is to evaluate the results of the selected categories of the questionnaire survey, which was carried out in the territory of Pisek City Forests, Ltd. (hereinafter referred to as "of Pisek City Forests"). The questionnaire survey constituted a part of a research focused on the economic evaluation of the recreational potential of forest ecosystems. This article concentrates on determining customers' willingness to pay for using forest-logging roads and bike paths located in the territory of the forest enterprise for recreational purposes.
In 2016, the research was financed by the project of the Internal Grant Agency (IGA) of Mendel University in Brno in its Department of Forest and Wood Products Economics and Policy and by the Department of Landscape Management.

The recreational use of an area is often related to the term "tourism."

Tourism, like any other human activity, has an impact on a community and a place from where it actively operates. The term impact is often negatively interpreted, and it does not have to always be harmful. In reality, tourism can have a positive socio-economic impact on 
a destination, and in some cases even a positive impact on the environment (Lück 2008).

Although opinions about the impact of tourism are still rather controversial, it is clear that tourism remains one of the main economic forces in the world (Weaver 2001).

Forests are ideal places for tourism activities of various kinds. By offering those activities, a forest fulfils a so-called recreational function, which comes under the socio-economic ecosystem services.

Ecosystem services are defined as direct and indirect benefits that people obtain from ecosystems (see, for example, Haines-Joung and Potschin 2010, 2013). Evaluation of the ecosystem services represents the first step in documenting changes in their nature and availability (Bush et al. 2012). The evaluation of changes in ecosystems linked with the living standard of inhabitants is a fundamental conceptual framework of Millenium Ecosystem Assessment (Alcamo et al. 2005).

According to the Common International Classification of Ecosystem Goods and Services (CICES), the recreational function can be classified as a cultural thematic category, which includes all the non-material, and normally non-consumptive, outputs of an ecosystem that affect physical and mental states of people (HainesYoung and Potschin 2013).

The valuation of ecosystem services is the first step towards documenting changes in their nature and availability. In addition to the assessment of ecosystem services, it is useful to provide an economic quantification of these services (Busch et al. 2012).

For a long time, support for recreational activities is one of the important features of the regional development policies based on the parallel evolution of development theories and tourism theories after the Second World War (Telfer 2002).

In the market environment, the urgency of the need to express the values of the ecosystem functions of forests in the form of money, i.e. to value them, is increasing. Most often, methods of extra-market valuation are used to value the functions of the forest ecosystems. These methods can be sorted into methods based on individuals' preferences (see, for example, Harris 2006; Šálka et al. 2008; Seják et al. 2003; Glover 2010; Soukopová et al. 2011) and methods based on experts' (non-preferring) approach (see, for example, Šišák and Pulkrab 2008; Vyskot et al. 2003; Seják et al. 2010).
The recreational value is usually determined using the travel cost method (TCM) or the contingent valuation method (CVM); the approach concentrated on the willingness to pay (WTP) is used most often. TCM is one of the several methods developed mainly in the USA in the 1960s to assess the value and demand for environmental possessions and services. A meta-analysis of studies, which employ the travel cost method applied to forest recreation, was done by Zandersen and Tol (2008). Methods based on the willingness to pay are broadly used in case studies focused on the evaluation of the recreational value of protected areas (see for instance Verbič and Slabe-Erker 2008; Hakim et al. 2011). In the Czech Republic, it was employed by Šišák (1993) for example; he used it for evaluation of the importance of the social aspects of forest functions. Bernath and Roschewitz (2008) used the method to evaluate the recreational benefits of municipal forests. Mayor et al. (2007), who evaluated the economic value of the recreational sources using the case of Irish forests, focused on the comparison of TCM and CVM.

\section{Material AND Methods}

The Pisek City Forests is a company founded by the city of Pisek to manage a forest area of 6,500 hectares. The company is owned by the city of Pisek to which it is accountable for its management. The running of the enterprise is also supervised by the appropriately elected members of the supervisory board. The forest administration, which is divided into 11 sections, ensures the overall running of the enterprise and governs the forest rangers. Its forestry assets are large; they reach from the forest Boudy u Mirotic in the northern part of the district through the forests around Dědice, on Lísek, and in Sloupovny to the mountain range of Písecké Hory, which is a part of the National Park Písecké Hory and lies near Albrechtice nad Vltavou (Pisek City Forests 2015).

When dealing with the project, both qualitative and quantitative methods of research were used.

The qualitative analysis of documents and publications is a fundamental methodical procedure (Früh 1991).

Furthermore, information gained in a preceding research was used, specifically in the research carried 
out by the research team of the Faculty of Forest and Wood Technology (hereinafter referred to as "FFWT") of Mendel University in Brno (Hlaváčková et al. 2015; Hlaváčková and Březina 2016) whose results have already been published.

Questionnaire survey was chosen as the tool for obtaining the primary data; this survey was in the form of a structured interview by means of which the visitors' willingness to pay for recreational use of the area was investigated, as well as the travel costs related to the journey into the researched area.

An interview is a technique of gathering information from the field during which the required information is gained from the investigated persons via targeted questions asked "face to face". Hence it is an interpersonal contact (Meuser and Nagel 1991). The term "structured" expresses the fact that the questions are formulated precisely and in a given order. Its advantage is the possibility to gain detailed information. Its weaknesses, on the other hand, are that it is time-consuming and respondents are not willing to answer the questions.

The questionnaire was developed on the basis of publications and case studies of foreign authors (see e.g. Bateman et al. 2002; Verbič and Slabe-Erker 2009; Bernath and Roschewitz 2008), which focused on the willingness to pay. Their authors reach an agreement that there is no universal method of surveying respondents' willingness to pay for ecosystem services, yet they provide some instructions on how to proceed. According to Bateman et al. (2002), a questionnaire should include

- the purpose,

- questions determining the respondents' stance towards general questions related to possessions or services,

- questions determining the way in which respondents use possessions or to which extent the respondents know them; the aim of these questions is to distinguish the users of the possessions from those who do not use them,

- a value assessment scenario (e.g. the payment method, the amount of payment), and

- socio-economic specifications.

The questionnaire was developed with regard to the above-mentioned aspects. The purpose of the questionnaire, i.e. an explanation of the research including its description and its main goal, was stated in its heading. Consequently, the respondent's sex was also request- ed. The main part of the questionnaire consisted of 22 questions. The first four questions were concerned with socio-economic characteristics of the respondents (determination of their age, education, job, and place of residence). The next nine questions dealt with the use of the interest area. The respondents answered questions concerning the frequency of their visits to the place, the way in which they had learned about it, the sufficiency of information about the place, seasons in which they visited the place most often as well as the reasons for their visits, the types of sport activities they did in the area and whether these were supported with sufficient infrastructure, or whether there was potential for further development of the infrastructure. The subsequent questions were based on the travel cost method. Four questions were asked about respondents' journeys - the distance from their place of residence, the type of transport they used for this type of travel, travel costs and expenditure that would be incurred for staying at the place. The following four questions concentrated on determining the respondents' willingness to pay fees for entering the area and on the maximum fee that the respondents would be willing to pay. The last question was an additional one in which the respondents could state their own comments concerning the questionnaire.

The questionnaire was processed using Microsoft Office Excel 2016.

The questionnaire survey was carried out in four localities from July to October 2016, each time for one week of a month from Monday to Friday, from 9 a.m. to 5 p.m.

For the survey, the most frequent forest-logging roads in the interest area were chosen, specifically, the forest-logging roads in Otavská, Flekačky, Obora and Amerika. During the monitored period, students of FFWT distributed 705 questionnaires.

The individual analysed questions included the below-mentioned categories of answers:

1. Gender: $\circ$ Female $\circ$ Male

2. To what age group do you belong?
$\circ 0-17 \quad \circ 18-25$
○ 26-39 $\circ 40-54$
○ 55-64
$\circ 65$ and more

3. What is your gross monthly income?
○ 0-10 000 CZK ○ $11000-20000 \mathrm{CZK}$
○ 21 000-30000 CZK ○ $31000-40000 \mathrm{CZK}$
○ 41 000-50 000 CZK $\circ$ above 51000 CZK 
4. How this place is far from your place of residence?
$\circ$ up to $1 \mathrm{~km} \quad \circ 1-10 \mathrm{~km} \quad \circ 11-50 \mathrm{~km}$
○ 51-100 km o 101-200 km o over $200 \mathrm{~km}$

5. Estimate the cost of travel on your journey to this place:

$\circ$ up to $50 \mathrm{CZK} \circ 50-100 \mathrm{CZK} \quad \circ 100-200 \mathrm{CZK}$

○ 200-500 CZK $\circ$ above $500 \mathrm{CZK}$

6. Are you willing to pay a fee to enter the area you used for recreation?

$\circ$ yes $\circ$ no

7. What percentage of the travel cost would you be willing to pay for enter into this area, if the user fees will be introduced?
$\circ 0 \% \quad \circ 0-10 \% \quad \circ 11-30 \% \quad \circ 31-50 \%$
$\circ 51-75 \% \quad \circ 75-100 \% \quad \circ$ more than $100 \%$

8. If you could decide to allocate your payment of income tax, how much $\%$ of the payments you will allocate to improve recreational functions in this area? $\circ 0 \% \quad \circ 1-2 \% \quad \circ 3-5 \% \quad \circ 6-10 \%$

$\circ$ more than $10 \%$

A correlation of the selected data was made using Microsoft Office Excel 2016.

\section{Results}

The outputs of the research contain summary and discussion of chosen research results focused especially on willingness of visitors to pay for the recreational use of Pisek City Forests. The results are accompanied by their graphical representation.

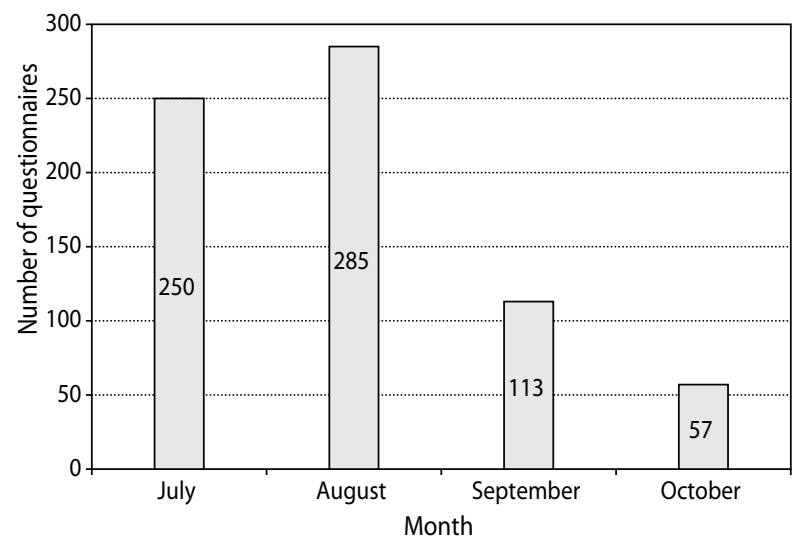

Figure 1. The number of questionnaires distributed to of Pisek City Forests
A total of 705 questionnaires in four localities in total during the periods stated in the Material and Methods section. Respondents always did not answer all the questions in the questionnaire. Among the respondents, $51 \%$ were male and $49 \%$ female visitors. The largest category consisted of people in the age group of 26-39 years, who made up approximately $26 \%$ of all the respondents. Figure 1 states quantities of the distributed questionnaires in individual months.

The weather and the summer vacation in July and August had a demonstrable impact on the quantity of filled questionnaires in the individual months.

Another important factor is the fact that the forests in the observed area fall into the category of suburban forests and thus they are frequently visited especially by local inhabitants. This statement is confirmed by Figure 2, which states distance of the place of residence of respondents.

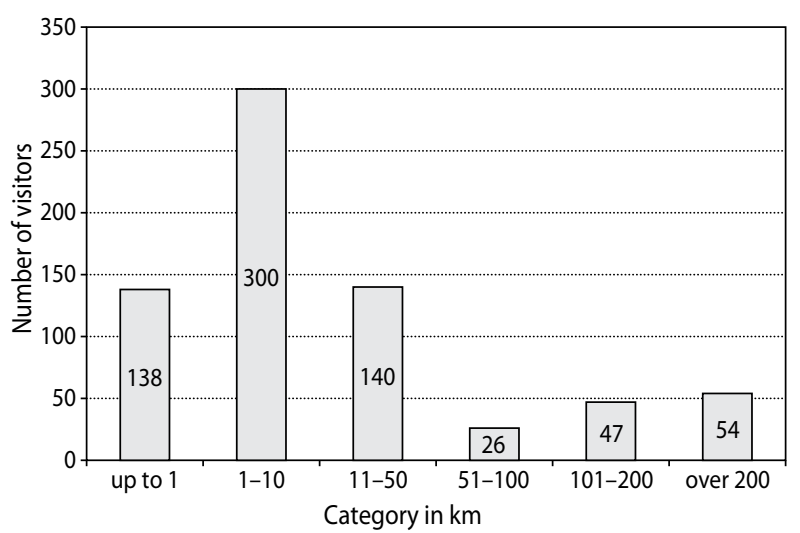

Figure 2. The distance from the place of the visitor's residence

It is apparent from the figure that approximately $62 \%$ of visitors have the forest areas located up to $10 \mathrm{~km}$ from their residence. This statement was also confirmed by the circle method that investigated the distribution of visitors from their residence. According to this method, it was found that approximately $82 \%$ of visitors have the forest area located up to $50 \mathrm{~km}$ from their residence.

Figure 3 implies that there is the medium strong dependence of visitors on transport distance from the areas of Pisek City Forests. The coefficient of determination is $R^{2}=0.4373$ and the correlation coefficient is $R=0.6613$. We can state that the most attractive distance for visitors is up to $50 \mathrm{~km}$ from their place of residence. 


\section{OPEN}

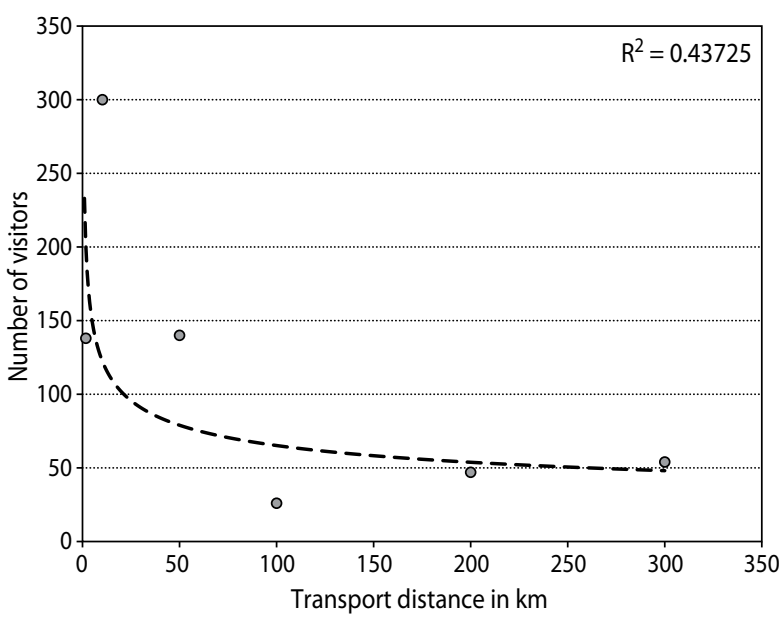

Figure 3. The dependence of visitors to the transport distance

In the majority of cases, the amount of travel costs incurred by visitors to get to the observed locality is dependent on distance from their place of residence. The surveyed cost amounts were divided into categories. Figure 4 shows categories of the visitor's travel costs.

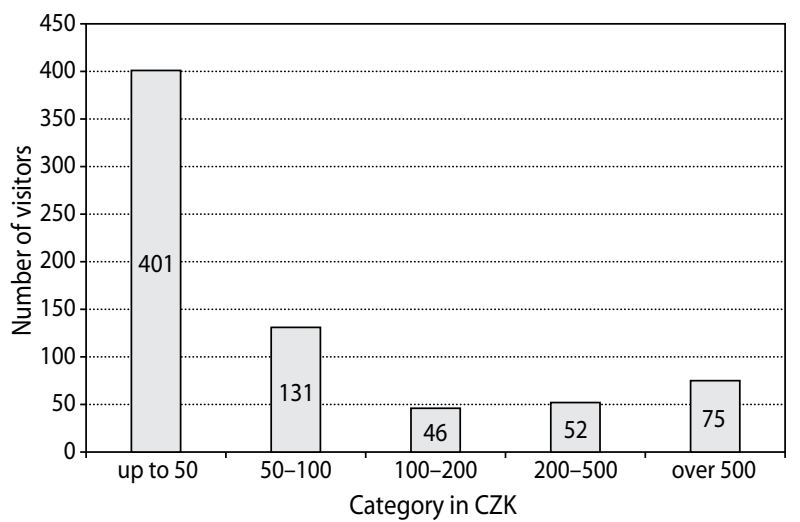

Figure 4. Travel costs of visitors

The figure implies that approximately $57 \%$ of visitors estimated the amount of their travel costs connected with travelling to the given locality at less than $50 \mathrm{CZK}$.

It is implied from Figure 5 that there is the strong direct dependence of visitors on the amount of travel costs for individual locations in of Pisek City Forests. The coefficient of determination is $R^{2}=0.7272$ and the correlation coefficient is $R=0.8528$. It is apparent that the amount of travel costs of 532 visitors did not exceed $100 \mathrm{CZK}$.

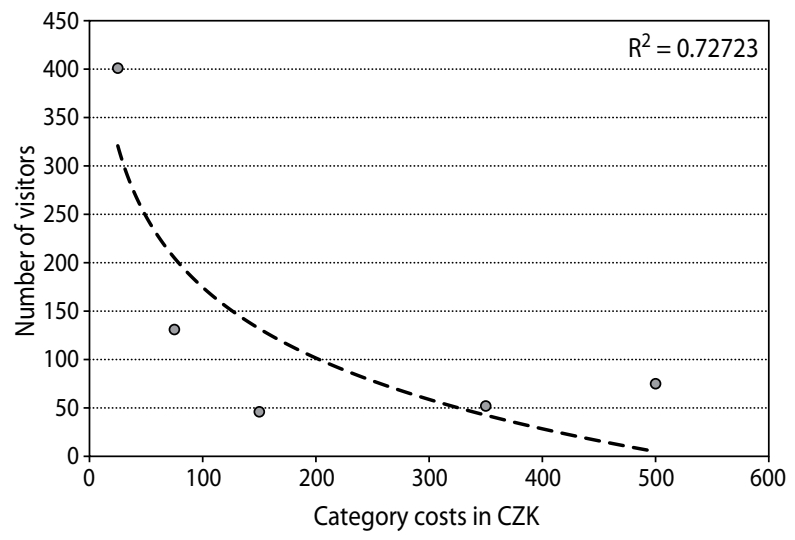

Figure 5. The dependence of visitors to travel costs

Furthermore, willingness of visitors to pay for entry into the observed area or willingness to pay for the recreational function offered by forest ecosystems in the observed area was surveyed. This part of questionnaire contained four questions. In the first of them interviewees were asked if they are even willing to pay the fee for entry into the area used for recreation. Answers to three remaining questions are an extension of this question. Willingness to pay for entry into the area used for recreation was expressed by $44 \%$ of respondents.

The willingness to pay is related to the amount of income; therefore respondents were asked about their gross monthly income. The answers imply that $63 \%$ of visitors do not have gross monthly income higher than 20,000 CZK.

Two further questions were related to the fee for the area use. Figure 6 states the results of answers for the first question asking how many percent of travel costs would be respondents willing to pay for entry to the given area if there were user fees introduced.

In spite of the number of answers in the first category, where visitors are not willing to pay any share of travel costs for entry into the area, it does not fully correspond with the quantity of answers to the question whether visitors are willing to pay for entry to the area (the difference is approximately 40 respondents). Low willingness to pay for entry to the area can be seen from the graph in Figure 6.

The graph in Figure 7 shows that even given a chance to decide how the income (profit) tax they pay into the public budget out of their salaries is used, still about $31 \%$ of respondents were unwilling to allocate even $1 \%$ of the tax amount for these recreational functions. In general, 


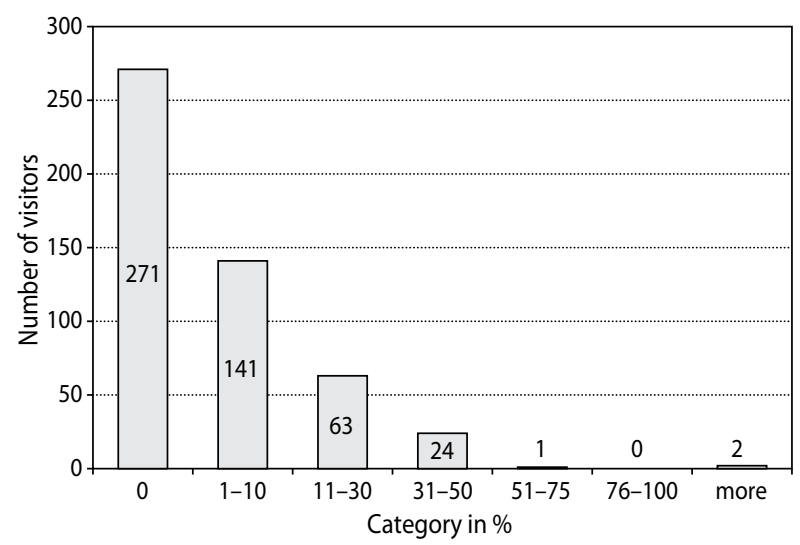

Figure 6. A percentage share of travel costs which visitors are willing to pay for the entry into the area used for recreation

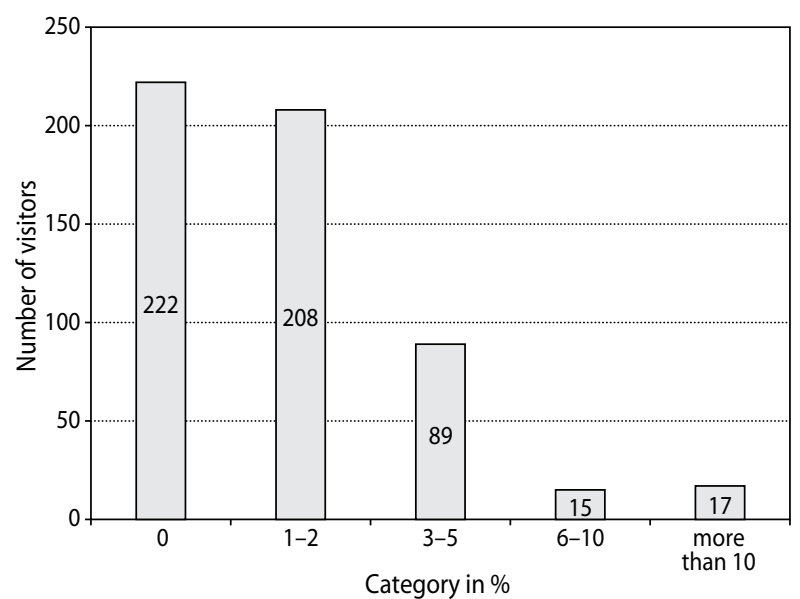

Figure 7. A percentage share of the income tax, which visitors are willing to allocate to improve the recreation function of the interest area

however, it may be stated that respondents would be willing to allocate a portion of their statutory levies for a specific area, in this case to improve the recreational opportunities in of Pisek City Forests.

\section{Discussion}

The effectiveness of tourism activities manifests itself by economic benefits for the visited area in the form of a transfer of wealth and investments from wealthier and more developed areas into those poorer and less developed (Sharpley 2002). The main carriers of this transfer shall be the expenditures of the visitors to the target area and the investments into the tourism infrastructure by enterprises from the areas generating the tourists, including all their positive and negative impacts (Williams 2000). The idea of supporting such tourism activities that are friendly to its environment asserted itself quite quickly, especially with regard to the physical impacts of tourism on its environment (Hall and Frost 2009).

Yet, over a long period, tourism activities affect their environment on a wide scale with a very intensive impact; in bibliography, these are usually structured using auxiliary division into three categories - the economic impacts (e.g. Gökovali and Bahar 2006; Katircioglu 2009; Lew 2011; Ivanov and Webster 2013; Tang and Abosedra 2014), the environmental impacts (e.g. Marzano and Dandy 2012; Barros A. et al. 2013; Oian 2013; Newsome 2014) and the socio-cultural impacts (e.g. Daldeniz and Hampton 2013; Thomas et al. 2013). They often result in degradation of the environment and the local culture as well as in the destruction of local resources, both directly and indirectly (Williams 2000). This is accompanied by degradation of sources of tourism itself. If this degradation are not rectified, it can lead to the tourists and consequently the tourism enterprises moving to other places and leaving behind the place and the local inhabitants deprived of sources of their growth (Butler 1980; Williams 2000). Traditionally, this development is connected with the tragedy of the commons (Hardin 1968). Luckily, since the 1960s some groups have already known that, in the long-term view, the wild development of tourism entails more losses than profits (not only economic ones but mainly environmental and cultural). Therefore, public institutions and, eventually, enterprises too adopted measures to diminish negative impacts of visits at the target places (Hall and Frost 2009).

The aim of the complex monitoring of tourism and visits in general is to provide basic information about the number of visitors and data concerning time variability of visits (within a day, a week, calendar months and seasons) and spatial distribution of visits over the target area (Zahradník et al. 2012). A standard output is also data about the structure of visitors' opinions. Lately, the monitoring of visits is one of the main activities of administrations of large-scale protected areas in the field of tourism (Bláha 2010; Kos 2010), but it is suitable in areas where conflict of interests influencing of the use of the area by other interest groups occurs. 
Due to the above-mentioned reasons, the urgency of the need to express the values of the non-production functions of forests (attesting value in terms of money), has been increasing over the last decades. This need originates from clashes of private and public interests regarding the opitmal rate and way of use of the environmental resources in the landscape of which forests are of the deciding importance (Hlaváčková and Šafařík 2013).

The recreational value is usually determined using the travel cost method, the contingent valuation method or, prevailingly, the approach concentrated on the willingness to pay.

Tutka and Kovalčík (2008) dealt with the possibilities of evaluation of the recreational function of forests in Slovakia using a combination of both the methods. Nevertheless, the authors calculated the value of a single visit.

In 2013, 2014 and 2015, a research focused on the determination of the value of recreation was carried out in the territory of the school forest enterprise, Masarykův les Krrtiny. In 2013, 1581 structured interviews were carried out, 1588 interviews were done in 2014 and 1843 interviews in 2015. Each time, the surveys were conducted in four localities and individual forest districts. The results of the individual years show similar characteristics. Approximately one-third of the respondents consisted of visitors aged 26-39. Most visitors were local inhabitants residing within $10 \mathrm{~km}$ from the visited areas. This is related to maximum travel cost, swhich usually did not exceed CZK 50.00. The most problematic questions of the preceding surveys were also linked with the willingness of the respondents to pay for ecosystem services (Hlaváčková et al. 2015; Hlaváčková and Březina 2016).

Generally, the research shows that the visitors of the territory are not willing to pay for using the recreational function of a forest ecosystem. The authors of the studies conducted abroad and focused on the evaluation of the economic contribution of ecosystem functions have reached the same conclusion (e.g. Mayor et al. 2007; Bernath and Roschewitz 2008).

\section{Conclusion}

This contribution presents the results of the research conducted in the territory of Pisek City Forests by the Department of Forest and Wood Products Economics and Policy and by the Department of Landscape Management within the scope of the project of the Internal Grant Agency of the Faculty of Forestry and Wood Technology of Mendel University in Brno in 2016.

The article focuses on the research survey about travel costs of visitors to the area and their willingness to pay for the recreational function offered by Pisek City Forests. The methodical approach is based on the combination of the contingency method and the method of travel costs. The secondary research of domestic and foreign resources were also analysed. The main method of the primary research was the structured interview. The interview was conducted by students of the Faculty of Forestry and Wood Technology in four localities of Pisek City Forests, always for 1 week in a month from June to October. In total 705 questionnaires were filled by the respondents. More than a half of the respondents were men. The visitors were in the age of 26-39 years. The majority of respondents had their residence up to $50 \mathrm{~km}$ from the locality. Approximately $76 \%$ of visitors did not spend more than 100 CZK per travel. It was found in the results of the questionnaire survey that visitors are not very willing to pay for recreational function, which is given by the interest area and it is especially because the forests in the area of Pisek City Forests are perceived as public asset and thus access to them should be without fee. Furthermore, there were problems with the method found, especially in expressing real willingness to pay and obtaining relevant numbers from respondents. Thus necessity to find a new way of evaluation of recreational potential of the area based on relevant economic data was confirmed.

This article contributes to the research of the area of valuation of forest functions and, above all, it presents a starting point for the economic evaluation of real cash flows resulting from the recreational use of the interest area.

\section{ACKNOWLedgement}

The paper was prepared with the support of the Internal Grant Agency project of the Faculty of Forestry and Wood Technology, Mendel University in Brno No. LDF_VT_2017006. 


\section{References}

Alcamo J. et al. 2005. Millennium ecosystem assessment: Ecosystems and human well-being. Island Press, Washington, DC. http://www.maweb.org/en/ Framework.aspx. Accessed 26 September 2014.

Barros A., Gonnet J., Pickering C. 2013. Impacts of informal trails on vegetation and soils in the highest protected area in the Southern Hemisphere. Journal of Environmental Management, 127, 50-60.

Bateman I.J., Carson R.T., Day B., Hanemann M., Hanleys N., Hett T., Jones-Lee M., Loomes G., Mourato S., Ozdemiroglu E., Pearce D., Sugden R., Swanson J. 2002. Economic valuation with stated preference techniques: a manual. Edward Elgar, Cheltenham, UK.

Bernath K., Roschewitz A. 2008. Recreational benefits of urban forests: Explaining visitors' willingness to pay in the kontext of the theory of planned behavior. Journal of Environmental Management, 89, 155-166.

Blaha P. 2010. The results of the monitoring and their practical application - Liberec Region. Ochrana prírody, Special issue.

Busch M., La Notte A., Laporte V., Erhard M. 2012. Potentials of quantitative and qualitative approaches to assessing ecosystem services. Ecological Indicators, 20, 89-103.

Butler R.W. 1980. The concept of a atourist area cycle of evolution: Implications for management of resources. Canadian Geographer-Geographe Canadien, 24 (1), 5-12.

City Pisek Forests, Ltd. 2016. Profil společnosti. [Company Profile]. http://www.lmpisek.cz/o-nasi-spolecnosti/profil-spolecnosti. Accessed 30 September 2016.

Daldeniz B., Hampton M.P. 2013. Dive tourism and local communities: Active participation or subject to impacts? Case studies from malaysia. International Journal of Tourism Research, 15 (5), 507-520.

Früh W. 1991. Inhaltsanalyse: Teorie und Praxis. Ölschläger, Munchen.

Glover D. 2010. Valuing the environment. Economics for a sustainable future. International Development Research Centre, Ottawa.

Gökovali U., Bahar O. 2006. Contribution of tourism to economic growth: A panel data approach. Anatolia, 17 (2), 155-167.
Haines-Young R., Potschin M. 2010. Proposal for a Common International Classification of Ecosystem Goods and Services (CICES) for Integrated Environmental and Economic Accounting (V1). 21st March 2010. Report to the European Environment Agency.

http://unstats.un.org/unsd/envaccounting/ceea/meetings/UNCEEA-5-7-Bk1.pdf. Accessed 26 September 2014.

Haines-Young R., Potschin M. 2013. Common International Classification of Ecosystem Services (CICES): Consultation on Version 4, August-December 2012. Report to the European Environment Agency, http://cices.eu/wp-content/uploads/2012/07/CICESV43_Revised Final_Report_29012013.pdf. Accessed 26 September 2014.

Hakim A. R., Subanti S., Hambunan M. 2011. Economic valuation of nature-based tourism object in Rawapening, Indonesia. An application of travel cost and contingent valuation method. Journal of Sustainable Development, 4 (2), 91-101.

Hall C.M., Frost W. 2009. Introduction: The making of the national parks concept. In: Tourism and national parks: International perspectives on development, histories and change (eds.: W. Frost, C.M. Hall). Routledge, London, 3-15.

Hardin G. 1968. The tragedy of the commons. Science, 162 (3859), 1243-1248.

Harris J. 2005. Environmental and natural resource economics. A conterporary approach. Houghton Mifflin, Boston.

Hlaváčková P., Březina D. 2016. Economic evaluation of the recreational use of forests: A case study of the Training Forest Enterprise Masaryk Forest Krrtiny. Journal of Forest Science, 62 (9), 389-398.

Hlaváčková P., Březina D., Meňházová J. 2015. Selected results of survey focused on the economic assessment of forest ecosystem services. Journal of Forest Science, 61 (7), 282-290.

Hlaváčková P., Šafařík D. 2013. Methodological bases of quantifying the importance of recreational functions of forests in the local economy - presentation of the project. In: Financovanie 2013 LesyDrevo. Technická univerzita vo Zvolene, Zvolen, 125-131.

Ivanov S.H., Webster C. 2013. Tourism's contribution to economic growth: A global analysis for the first 
decade of the millennium. Tourism Economics, 19 (3), 477-508.

Katircioglu S.T. 2009. Revisiting the tourism-ledgrowth hypothesis for Turkey using the bounds test and Johansen approach for cointegration. Tourism Management, 30 (1), 17-20.

Kos J. 2010. The results of the moitoring and their use in practice - Podyjí National Park Ochrana přirody, Special issue.

Lew A.A. 2011. Tourism's role in the global economy. Tourism Geographies, 13 (1), 148-151.

Lück M. 2008. The Encyclopaedia of Tourism and Recreation in Marine Environments. Wallingford, UK; CAB International, Cambridge, MA.

Marzano M., Dandy N. 2012. Recreationist behaviour in forests and the disturbance of wildlife. Biodiversity and Conservation, 21 (11), 2967-2986.

Mayor K., Scot S., Tol R.S.J. 2007. Comparing the travel cost method and the contingent valuation method: An application on convergent validity theory to the recreational value of Irish forest. Working Paper. The Economic and Social Research Institute (ESRI), Dublin.

Meuser M., Nagel U. 1991. Experteninterviews - vielfach erprobt, wenig bedacht. In: Qualitativ-empirische Sozialforschung (eds.: D. Garz, K. Kraimer). Springer, Opladen, 441-471.

Newsome D. 2014. Appropriate policy development and research needs in response to adventure racing in protected areas. Biological Conservation, 171, 259-269.

Oian H. 2013. Wilderness tourism and the moralities of commitment: Hunting and angling as modes of engaging with the natures and animals of rural landscapes in Norway. Journal of Rural Studies, 32, 177-185.

Seják J. et al. 2010. The evaluation of functions and services of ecosystems of the Czech Republic. Univerzita J. E. Purkyně v Ústí nad Labem, Ústí nad Labem.

Seják J., Dejmal I. et al. 2003. The evaluation and valuation of habitats of the Czech Republic. Český ekologický ústav, Praha.

Sharpley R. 2002. Tourism and development - A vehicle for evelopment? In: Tourism and development.
Concepts and issues (eds.: R. Sharpley, D.J. Telfer). Channel View Publications, Clevedon, 11-34.

Soukopová J., Bakoš E., Doleželová M., Kaplanová B., Kulhavý V., Neshybová J. 2011. Environmental Economics. Masaryk University, Brno.

Šálka J., Trenčiansky M., Bahula P., Balážová E. 2008. Environmental economics. Technická univerzita vo Zvolene, Zvolen.

Šišák L. 1993. Willingness to pay potentially as a method of valuing the importance of social aspects of forest functions. Lesnictvi - Forestry, 93 (3), 151-160.

Šišák L., Pulkrab K. 2008. The assessment of the societal socio-economic importance of forest functions. Česká zemědělská univerzita v Praze, Praha.

Tang C.F., Abosedra S. 2014. The impacts of tourism, energy consumption and political instability on economic growth in the MENA countries. Energy Policy, 68, 458-464.

Telfer D.J. 2002. The evolution of tourism and development theory. In: Tourism and development. Concepts and issues (eds.: R. Sharpley, D.J. Telfer). Channel View Publications, Clevedon, 35-80.

Thomas F., Kapoor A., Marshall P. 2013. Tourism development and behavioural changes: evidences from Ratanakiri province, Kingdom of Cambodia. Journal of Tourism and Cultural Change, 11 (3), 208-219.

Tutka J., Kovalčík M. 2008. Estimating the value of the recreational forest functions in Slovakia through the contingent valuation method and the travel cost method. Lesnický časopis - Forestry Journal, 54 (1), 99-107.

Verbič M., Slabe-Erker R. 2009. An econometric analysis of willingness-to-pay for sustainable development: A case study of the Volčji Potok landscape area. Ecological Economics, 68, 1316-1328.

Vyskot et al. 2003. Quantification and evaluation of forest functions in the Czech Republic. Ministerstvo životního prostředí ČR, Praha.

Weaver D.B. 2001. The Encyclopedia of ecotourism. CABI Publishing, New York.

Williams S. 2000. Tourism geography. Routledge, London.

Zandersen M., Tol R.S.J. 2009. A meta-analysis of forest recreation values in Europe. Journal of Forest Economics, 15, 109-130. 